\title{
O "milagre da onipotência" e a dispersão dos vadios: política urbanizadora e civilizadora em São Paulo na administração do morgado de Mateus (1765-1775)
}

\section{AMILCAR TORRÃO FILHO*}

Resumo: O morgado de Mateus foi o primeiro governador da Capitania de São Paulo após sua restauração em 1765 . Uma das principais ações de seu governo foi a urbanização da capitania, com a ereção de novas vilas, e a sua reorganização espacial, de acordo com as novas diretrizes ilustradas do governo pombalino. Sua intenção era civilizar os habitantes, fixando-os em povoações civis, submetendo-os à autoridade real.

Abstract: Morgado de Mateus was the first governor of São Paulo Captaincy after the restauration of 1765. One of the first actions of his government was the urbanization of captaincy, with the erection of new villages, and the spacial reorganization, according with the new enlightened norms of Pombaline government. His goal was to civilize the inhabitants, to settle them in civil villages, and to submit them to the Royal authority.

Palavras-chave: São Paulo. Morgado de Mateus. Urbanização.

Key-words: São Paulo. Morgado de Mateus. Urbanization.

Tudo isto e muito mais me é ainda necessário para restabelecer este estado de letargo, em que se achava [a capitania de São Paulo]; o criá-lo de novo seria muito menos, porque a criação das cousas é obra da Natureza; o ressuscitá-las milagre da Onipotência. Para Deus criar o Mundo bastou-lhe uma palavra, e para o restaurar desceu dos Céus, gastou trinta anos, e custou-lhe a vida.

Morgado de Mateus, carta ao rei, de 20 de junho de 1768

* Mestre em História e doutorando pela Unicamp. Este artigo é parte de minha dissertação de mestrado Paradigma do caos ou cidade da conversão?: a cidade colonial na América portuguesa e o caso da São Paulo na administração do morgado de Mateus (1765-1775), Unicamp, 2004, que contou com apoio financeiro da CAPES.

Estudos Ibero-Americanos. PUCRS, v. XXXI, n. 1, p. 145-165, junho 2005 
Em 1748 a capitania de São Paulo é desmembrada das Minas Gerais, quando se criam as capitanias de Goiás e Mato Grosso, sendo então administrada por um governador em Santos, sem patente de capitão-general e submetido ao Rio de Janeiro. Depois de um requerimento da câmara de Piratininga, a capitania é restaurada por Sua Majestade. O conde da Cunha, vice-rei do Brasil entre 1763 e 1767, também escreve ao rei em 12 de agosto de 1764, afirmando estar reduzida a capitania a um estado lastimável, sendo impossível governar as capitanias de São Paulo e Rio de Janeiro conjuntamente, pelas distâncias e por serem os habitantes de São Paulo "excessivamente inquietos e revoltosos, em território abundante de minas de ouro e nas vizinhanças dos castelhanos". ${ }^{1}$ Em carta ao conde da Cunha, Francisco Xavier de Mendonça Furtado afirma que por conta do "miserável estado a que se achava reduzida", pela falta de governo e pela proximidade da cidade de São Paulo com o novo descoberto de São João de Jacuri, Sua Majestade decidira nomear a D. Luís Antônio de Souza Botelho Mourão, o morgado de Mateus, para governador e capitão-general de São Paulo. Dentre suas atribuições estava a definição dos limites da capitania com a das Minas Gerais e Goiás além de sua recuperação, dado o miserável estado em que se encontrava. ${ }^{2}$ Interesses diversos orientaram a restauração da capitania de São Paulo: a mudança do eixo político para o sudeste da colônia, com a transferência da capital para o Rio de Janeiro em 1763, o desejo da Coroa em policiar o contrabando das minas, os interesses dos mercadores paulistas em ter governo próximo, que atentasse aos seus interesses e as questões de fronteira com os castelhanos no sul, que por mais de uma vez quase chegaram à declaração de guerra entre os dois reinos ibéricos. E não devemos descartar também o desejo do governo pombalino de varrer de seus territórios e domínios a presença dos jesuítas, tão clara ainda em São Paulo do Campo mesmo anos depois de sua expulsão. Ou pelo menos era o que pensava o governo de D. José I.

Na capital piratiningana, a época também era de mudanças. Com a restauração da capitania, o Pátio do Colégio dos Jesuítas, expulsos em 1760, passou a se chamar Largo do Palácio, servindo a partir de 1766 como residência do novo governador. A presença dos inacianos deveria ser apagada das cidades e aldeamentos e seus símbolos de poder deveriam ser substituídos pela presença do Estado português. Em São Paulo, cidade baluarte construída pelos padres da companhia para consolidação do poder da Igreja e do Estado, enquanto aliado do papado, e também de sua própria ordem, a

DI, v. 11 , p. 209-211.

2 Ibid., v. 67, p. 144. 
transferência simbólica do poder era ainda mais necessária. Para isso o novo governador envidou todos os esforços possíveis para erradicar algumas das causas do que considerava o estado miserável da capitania: a presença jesuítica, ainda evidente nos espaços da cidade, a resistência dos "paulistas", "inquietos e revoltosos", em adotarem as novas diretrizes ilustradas de "gerência" da economia, da administração pública e da segurança trazidas pelo capitão-general e a enorme "preguiça" dos naturais da terra, vivendo como homens nas cidades e povoações e não nos sertões como feras.

\section{Um governador ilustrado}

D. Luís Antônio de Souza Botelho Mourão, o $4^{\circ}$ morgado de Mateus $^{3}$, nasceu em 21 de fevereiro de 1722, na propriedade de seus avós maternos, na freguesia de São Veríssimo de Riba, distrito da vila de Amarante. Recebeu educação militar de seu avô, D. Luís Antônio de Souza, governador do castelo de São Tiago da Barra da vila de Viana. Comandou a resistência à ofensiva franco-espanhola em 1762, durante a Guerra dos Sete Anos (1756-1763), tendo sido promovido a coronel de infantaria. Ao ser nomeado governador da capitania de São Paulo, possuía os títulos de morgado de Mateus, de Moroleiros, de Sabrosa e Cumieira, fidalgo da casa de Sua Majestade e de seu conselho, senhor donatário da vila de Ovelha do Marão, alcaide-mor da cidade de Bragança, comendador de Santa Maria de Vimioza da Ordem de Cristo e governador do castelo da Barra de Viana. Suas habilidades militares the garantiram a nomeação para a capitania de São Paulo, de acordo com as diretrizes do governo pombalino, de garantir a defesa da complicada fronteira sul da colônia com os castelhanos, a "recuperação" econômica e de introduzir novos e modernos elementos de governo e "gerenciamento" da administração pública e econômica.

3 Sobre o morgado de Mateus cf. Moura, Américo Brasiliense Antunes de. O governo do Morgado de Mateus no vice-reinado do Conde da Cunha. S. Paulo restaurado. RAMSP, São Paulo, V(LII): 1-155, nov., 1938; Jardim, Caio. A capitania de São Paulo (sob o governo do morgado de Mateus, 1765-75). RAMSP, São Paulo, V(LIII): 5-82, dez., 1938/jan., 1939; Neme, Mário. Um governador reformista no São Paulo colonial. Anais do Museu Paulista, São Paulo, XXIV: p. 9-53, 1970; Bellotto, Heloísa Liberalli. Autoridade e conflito no Brasil colonial: o governo do morgado de Mateus em São Paulo (1765-1775). São Paulo: Secr. de Estado da Cultura, Cons. Estadual de Artes e Ciências Humanas, 1979; Lewkowicz, Ida. Morgado de Mateus. In: Vainfas, Ronaldo (org.). Dicionário do Brasil colonial (1500-1808). Rio de Janeiro: Objetiva, 2000; Miranda, Lílian Lisboa. Governança e edilidade em São Paulo (1765-1775), São Paulo: USP, 2003 (tese de doutorado em História). 
Seus planos para a capitania eram, segundo Jardim, a militarização, visível nas tentativas de organizar tropas de ordenanças e na insistência em manter o presídio de Nossa Senhora dos Prazeres do Iguatemi, ${ }^{4}$ no Mato Grosso, o chamado "cemitério dos paulistas", pelo qual seria tão criticado, a regularização dos serviços de arrecadação de rendas, a disseminação de núcleos de povoamento pelo sertão, bem como tornar São Paulo "uma base para a resistência a movimentos bélicos [dos espanhóis] no sul e oeste". ${ }^{5}$ Essas diretrizes eram, na verdade, instruções dadas ao governador pelo então conde de Oeiras, que pretendia "constituir no Sul uma barreira defensiva e talvez, uma força ofensiva contra os castelhanos". 6 Tampouco constitui o morgado de Mateus uma exceção no universo de governadores coloniais portugueses; Nuno Monteiro observa que havia uma extrema aristocratização do cargo de vicerei, e muitas vezes o cargo de governador, ou capitão-general, era uma etapa antes da nomeação para um vice-reinado. Na segunda metade do século XVIII, a seleção dos governadores do Brasil torna-se mais rigorosa, como era com a Índia até então, sendo todos "fidalgos de primeiríssima nobreza do reino". ${ }^{7}$ Chegar a vice-rei, se podia fazer cair em desgraça ao ocupante do cargo em seu retorno ao Reino, também podia representar 'formas de 'acrescentar' as casas em honras e proventos doados pela Coroa em remuneração de serviços, podendo até constituir a via mais segura para se atingir tal objetivo".8 Assim, temos fidalgos preparados nos cargos de governança, como D. Luís Antônio em São Paulo, Francisco Xavier de Mendonça Furtado, irmão de Pombal, no Pará, ou Francisco Inocêncio de Souza Coutinho, cunhado de D. Luís, em Angola, todos imbuídos do desejo de levar a Ilustração Católica em voga no Portugal setecentista aos seus domínios, e cada um a sua maneira procurando diferenciar-se dos demais na esperança de um cargo mais vantajoso e com mais "mercês e tenças" a que teriam direito em caso de sucesso.

4 Presídio não tem o sentido de prisão, mas significa, segundo Bluteau, "gente de guarnição. Os soldados que estão em uma praça, para a guardar \& defender do inimigo". Vocabulario portuguez e latino. Coimbra: Collegio das Artes da Companhia de Jesu, 1712

5 Jardim, op. cit., p. 19

6 Bellotto, op. cit., p. 83

7 MONTEIRO, Nuno Gonçalo F. Trajetórias sociais e governo das conquistas: notas preliminares sobre os vice-reis e governadores-gerais do Brasil e da Índia nos séculos XVII e XVIII. In: FRAGOSO, João; BICALHO, Maria Fernanda; GOUVÊA, Maria de Fátima (orgs.). O Antigo Regime nos Trópicos: a dinâmica imperial portuguesa (séculos XVI-XVIII). Rio de Janeiro: Civilização Brasileira, 2001, p. 267.

8 Ibid., p. 269. 
Ao chegar no Brasil, D. Luís Antônio se chocará com o "atraso" e a falta de civilidade da capitania e da cidade de São Paulo. Ao menos é o que se depreende de sua correspondência, que serviu de base a tantos historiadores para compor o quadro de decadência e abandono das terras paulistas e, sobretudo, de sua população, bastarda, mameluca, inculta, enfermiça, não adaptada ao trabalho sistemático e ao aproveitamento de novidades como o arado, introduzido aqui pelo governador. É claro que o fidalgo português se sente incomodado com os desconfortos da América, mas muito das suas descrições têm como objetivo valorizar sua empreitada "civilizadora": quanto maiores os obstáculos que se lhe apresentem, mais valorizados são seus resultados.

Em ofício ao rei de 1 de dezembro de 1767, D. Luís Antônio se queixa da desordem e decadência que encontra na capitania que irá governar: das tropas não encontra mais do que ordenanças que, embora tivessem seus capitães-mores, estavam "faltas de disciplina e de obediência pela dispersão em que vivem os Povos, e pelo dos costumes". As povoações são todas pequenas e sem nenhum modo de ganhar a vida, "os campos incultos, tudo coberto de mata brava, a lavoura por mau método, pois só se planta em mato virgem", pela repugnância que têm os lavradores de se sujeitarem ao trabalho de "cultivarem os campos como nesse Reino. Apenas colhe cada um para o seu sustento próprio muito pouco sobra para se vender ao público". Ninguém aproveita, diz o governador, os recursos do país, achando-se o povo "reduzido a mais lastimosa pobreza". Não encontra o governador a população assentada em vilas e cidades como gostaria, afirmando que a

dispersão que se costuma habitar não possibilita a devida civilidade nem a necessária Doutrina Espiritual, pois procede que esquecidos os homens das obrigações com que nasceram, seguem a desordem natural dos seus costumes, uns adormecendo-se nos vícios, outros cometendo delitos, de que todos os dias se ouviam as tristes noticias. ${ }^{9}$

Ao conde de Oeiras descreve de modo não menos desolador o estado das coisas na capitania. D. Luís observou ao ministro que a cada dia se ia "formalizando mais nos inconvenientes que se seguem ao serviço de Deus e o de S. Maje., e ao bem comum deste Estado por causa do mau método da lavoura".10 Não usam os paulistas as terras "como nesse Reino", ou seja, de maneira intensiva e

9 AHU, São Paulo, cx. 5, doc. 18 [D. 333].

10 DI, v. 23, p. 1. 
comercial, preferindo-se ainda uma agricultura itinerante e extensiva. ${ }^{11}$ Falta a adequação da colônia às necessidades da Coroa: no raciocínio do governador isto se dá pela ausência da civilidade necessária aos povos para poderem adotar as normas "ilustradas" de produção e de povoamento, comuns às nações polidas da Europa, bem como da religião, a necessária aliada da monarquia na condução dos seus súditos. É o primeiro inconveniente que encontra D. Luís Antônio, a falta de religião, "e é certo que aonde se falta a Deus, que é o criador de tudo, o Sumo bem, e a fonte de toda a felicidade, não pode haver cousa boa". ${ }^{12}$ Um segundo inconveniente, muito ligado ao primeiro, é a "falta de Sociedade, pois sendo esta a principal das obrigações civis, se acha totalmente arruinada e caminha a passos largos para o seu precipício, levando atrás de si a ruína de todo o Estado". A falta de religião e a técnica de plantio considerada primitiva se unem para o morgado de Mateus na desintegração da sociedade. Esta técnica de plantio contribui para a ruína do Estado, "porque consistindo ela na união com que os Homens se ajudam uns aos outros, nada é tanto contra esta união, como o referido método de lavoura que se pratica". Finalmente uma terceira causa que é a falta de Justiça,

porque vivendo os homens fora de povoado, metidos pelos matos sem ouvirem mais do que a família, faltos de instrução, e de doutrina, e até dos primeiros princípios da nossa Fé, que hão de ser senão piores que feras, porque estas pela falta de aptidão, e de discurso podem fazer um dano semelhante; mas os homens dotados de talento, abandonados à lei da natureza, e criados entre as brenhas como feras, são capazes de outros maiores danos; e quando o não fazem se não pode esperar deles utilidade alguma, nem para o Reino do Céu, nem para o de S. Majestade que Deus Guarde...13

Um pouco adiante o governador esclarece melhor de quem estava falando como causadores da ruína de São Paulo; era a maior parte do povo da capitania, mas não aqueles "filhos do Reino que têm casas de negócio, fazendas, ou lavras estabelecidas, nem daqueles fidalgos paulistas que se conservam com seu modo

11 Muitos autores incorporaram as imagens do morgado de Mateus e de outros europeus sobre esta agricultura itinerante, ou de subsistência, para demonstrar a pobreza e precariedade econômica da capitania e da cidade de São Paulo. Kuznesof, por exemplo, afirma que a capital paulista era ainda no século XVIII caracterizada por "padrões seminômades de residência, acompanhados por uma agricultura de coivara" (Kuznesof, Elizabeth A. Household economy and urban development. São Paulo, 1765 to 1836. Boulder, CO: Westview, 1986, p. 77.

$12 D I$, v. 23, p. 1.

13 Ibid., p. 2. 
de vida [...] ou a maior parte do tempo em povoado, pois é certo que eles têm toda a civilidade que se requer". ${ }^{14}$ É destes homens rústicos que se queixa o governador, presos às superstições, abandonados à lei da natureza e sobretudo sem sujeição à Igreja e à Coroa, que impedem o seu trabalho na condução da capitania de forma racional, "ilustrada" e de acordo com os interesses de S. Majestade.

Como causa deste estado, afirma D. Luís Antônio ser a "suma preguiça, e negligência não só dos naturais, mas dos mesmos filhos do Reino que se conformam com ela, e aumentam". ${ }^{15}$ As fugas das povoações e os sítios volantes também são interpretados pelo governador como "preguiça" e desejo de fugir ao trabalho sistemático, fugas que aumentam na medida em que se criam as ordenanças, muitas vezes com recrutamento forçado, e aumenta também a cobrança de taxas para o reino. Além da preguiça, para o governador, concorria também a animosidade dos espíritos dos paulistas, "cujas propriedades tanto podem ser úteis ao Estado, como prejudiciais se não forem Governadas por uma certa máxima de Autoridade e respeito que os conserve mais na obediência com o modo que com o castigo". Entendia o governador que a "animosidade" dos paulistas poderia ser útil, por exemplo, na descoberta de novas riquezas no sertão, como fizeram os seus antepassados bandeirantes de que se gabavam as elites locais, ou na defesa militar das fronteiras com os castelhanos. No entanto, encontra o fidalgo português em sua capitania homens fugindo à cobrança de impostos e ao recrutamento, ou dedicando-se aos seus próprios interesses comerciais, sem atender aos interesses da Coroa. Esperava para isso animar os espíritos dos paulistas, "lembrando-lhes os progressos que fizeram seus antepassados sendo nestes sertões o flagelo de nossos confinantes inimigos [os espanhóis] lhes inspire, que para fazer renascer a glória dos seus progenitores, proponham levantar alguns terços de milícias".16 Para angariar a confiança e obediência dos paulistas, o morgado de Mateus reforça os aspectos simbólicos de seu poder: afirma que procurou

14 Ibid., p. 2-3.

15 DI, v. 23, p. 5-6. Algumas assertivas de Sérgio Buarque de Holanda, parecem ter como fonte as opiniões do morgado de Mateus. Não deixa de ser uma certa "preguiça", na visão deste autor, a maneira como o colono português se "adapta" aos hábitos indígenas, o mau uso do solo, tornando-o imprestável, a fuga da vida conversável embrenhando-se no sertão, reduzido à "dependência imediata da natureza" e o uso de técnicas indígenas "sem sequer o cuidado de aperfeiçoá-las" (Caminhos e fronteiras. São Paulo: Companhia das Letras, 1995, p. 60; 170).

16 Ibid., p. 119. 
conservar sempre os distintivos de mando na Casa, na Igreja, e na Rua; e também nas resoluções do Governo para que não desmentissem os olhos o que devia crer o entendimento: porque estas gentes que fazem vaidade de ser governados por um Grande, reconhecem o distinto caráter da Pessoa, e o Pleno Poder da Jurisdição que já alcançarão os Generais meus antecessores. ${ }^{17}$

Chegando a São Paulo, o novo governador se ocupou não apenas da fundação de novas povoações e vilas, confecção de mapas para melhor conhecimento do território, de seus caminhos e de suas riquezas, como pela história das povoações existentes, recebendo de Pedro Taques uma Informação Histórica sobre a fundação das vilas da capitania. 18 Mais do que estudar a história das primeiras fundações urbanas em São Paulo, o próprio governador elaborou uma memória histórica, em forma de resposta a algumas questões, que eram as seguintes: "Os princípios que teve a Capitania de São Paulo, que é das maiores do Brasil?; De que modo se formaram delas as Capitanias de Minas Gerais, e de Cuiabá e Mato Grosso e dos Goiazes?; Em que tempo floresceu mais?; E os motivos e razões porque tem decaído?". 19 O documento explica como se deu o povoamento da capitania, a fundação de suas principais vilas e as atividades de seus habitantes, sobretudo em relação à pacificação dos índios e à descoberta das minas. Destaca a restauração da capitania e a sua própria nomeação como governador, exatamente o tempo no qual ela "floresceu mais"; além da restauração, uma das causas da recuperação de São Paulo foi a fundação de "vinte e tantas povoações novas em diversas partes, pondo Párocos nos Sertões adonde acharam rapazes de 15 e 20 anos por batizar e homens de 40 anos por confessar".

A formação de povoações foi uma das primeiras e principais preocupações do morgado de Mateus; mesmo atendendo a determinações régias, a formação de freguesias, distritos e vilas estava de acordo com suas idéias para a promoção do crescimento econômico da capitania e era um dos motivos de orgulho de sua administração que ele não deixava de recordar ao rei e ao marquês de Pombal, tendo formado mais de vinte povoações em seus dez anos de governo. Para orientar sua política de "urbanização", D. Luís Antônio trocou correspondência com Francisco Xavier de Mendonça Furtado, Secretário de Estado da Marinha e Ultramar, pedindo informa-

17 Ibid, v. 19, p. 291-292.

$18 \mathrm{BN}$, Informação histórica sobre a fundação de algumas das primeiras vilas da Capitania de São Vicente, São Paulo, 3 jan. 1767. I-30, 24, 5. Arquivo de Mateus., doc. 05.

19 BN, Demonstração dos princípios e as primeiras Fundações da Capitania de São Paulo..., s.d. I-30, 24, 1. Arquivo de Mateus, doc. 16. Este documento e o citado anteriormente estão transcritos em Vianna, Hélio. São Paulo no Arquivo de Mateus. Rio de Janeiro: BN, Divisão de Publicações e Divulgação, 1969. 
ções sobre a fundação de novas povoações e ereção de novas vilas. Tendo levantado Furtado mais de setenta vilas quando fora governador do Grão-Pará e Maranhão, era a pessoa certa para dirimir as dúvidas do governador de São Paulo. Diz ele que imaginava que o secretário havia encontrado as mesmas objeções na criação de suas novas vilas, sobretudo com relação às côngruas dos párocos de povoações onde a população era pobre demais, por vezes transportada de outras partes, para poder arcar com esta despesa. Sua dúvida era sobre como pagar estes clérigos nos primeiros anos onde ainda não havia cultivo. Também perguntava sobre as dificuldades em casar estes homens dispersos, de partes distantes e sem condições de pagar as despesas do matrimônio, "motivo porque estas Capitanias estão tão pouco povoadas". ${ }^{20}$ Também questiona sobre as despesas com os emolumentos dos corregedores e gastos das câmaras, e destas dúvidas depreendemos quais eram os embaraços e as dificuldades encontrados pelo governador: os pagamentos aos clérigos e à burocracia administrativa das novas povoações e as dificuldades na formação de famílias estáveis e no estabelecimento de povoadores. ${ }^{21}$

Embora destaque questões econômicas para a criação de povoações, como o aumento da produção, do comércio e da arrecadação, o ponto fulcral de sua atividade povoadora é a civilidade, a sujeição das populações dispersas à autoridade da Igreja, sem tantos homens sem batismo e confissão, e ao Estado. Ao afirmar que a capitania estava despovoada por conta das dificuldades de se realizarem os matrimônios, isso não quer dizer que havia pouca população, uma vez que os índices de ilegitimidade eram altos em toda a colônia. Faltava a população legitimamente reconhecida pelo Estado e pela Igreja, casada pelo rito tridentino e com filhos legítimos, aptos ao exercício das obrigações da república; não era da falta de bastardos que se queixava o governador, mas de republicanos "úteis" e "nobres". Povoar significa também impor normas e regras de convivência que tornariam "menos possível o isolamento e a fuga em relação aos sistemas de convivência estabelecidos".22

20 AHU, São Paulo, cx. 5, doc. 28 [D. 345].

21 Na carta-instrução que deixa a seu sucessor, Martim Lopes Lobo de Saldanha, o morgado de Mateus alerta-o sobre estes problemas com os clérigos que, segundo ele, boicotavam as novas povoações para não se verem obrigados a residir em terras mal estabelecidas. "Pedia especial atenção do futuro governante para os Diretores das [vilas] mais recentes, que contavam com a má vontade dos párocos, entravando a ação governamental". Bellotto, op. cit., p. 334.

22 Hespanha, António Manuel. As vésperas do Leviathan. Instituições e poder político Portugal - séc. XVII. Coimbra: Almedina, 1994, p. 64. 
Em resposta à câmara de Curitiba, afirma que a "raiz e causa" dos inconvenientes da falta de um vigário de vara, que os camaristas apontam em carta anteriormente enviada, consiste unicamente

na dispersão, e irregularidade com que vivem os Povos deste Continente faltando a Deus e ao Rei e a todas as obrigações civis, vivendo sem religião, sem Justiça e sem Sociedade humana, de cujos erros se seguem infalivelmente todas as misérias que se estão experimentando; porque faltando aos homens todo o governo espiritual e temporal, é conseqüência infalível serem conduzidos pelas suas desordenadas paixões, de abismo em abismo.

Ordena então que se cumpra Carta Régia de 22 de junho de 1766, congregando os povos e fazendo-os

estabelecer em sítios acomodados e convenientes, para viverem juntos, como homens em Vilas e Aldeias, onde possam ouvir Missa e receber os Sacramentos na hora da morte, e serem sepultados em [solo] Sagrado, como católicos, e em vida serem governados pelos ditames da razão, e da justiça, vivendo em, sociedade como homens e não pelos matos como feras. ${ }^{23}$

Esta carta é claríssima na definição da Ilustração Católica a ser estabelecida na colônia americana: a sujeição dos homens, libertos de suas paixões desenfreadas pela ação ordenadora e racional da igreja, prestando-lhes os sacramentos, e do Estado, governando-os sob os ditames da razão, claramente entendida como sinônimo de subordinação.

Em ofício ao então marquês de Pombal, em 4 de setembro de 1771, o governador justifica o grande número de pessoas enviadas às expedições do sertão afirmando que elas eram convenientes às Reais Rendas, servindo de acrescentamento delas no aumento das dízimas, sobretudo procedente das "novas colônias que se vão fundando [...] com as quais se vão civilizando os Povos". Entende o governador civilizar os povos também no sentido de acostumálos ao pagamento dos impostos, já que observa que era tal a "ignorância ou malícia dos habitadores daqueles Sertões que se admiram de ouvir a palavra dízimos". ${ }^{24}$ O povoador de Nossa Senhora da Conceição do Mato Grosso das Campinas, Francisco Barreto Leme, escreve ao governador em 11 de agosto de 1774 pedindo que se fizesse uma nova demarcação do local escolhido para esta freguesia, mais favorável e "em que nos fique gente, cujas esmolas, e trabalhos sejam suficientes para continuação da nossa Matriz, e

23 DI, v. 67, p. 137-138. Carta de 19 de maio de 1767.

24 AHU, São Paulo, Mendes Gouveia, cx. 27, doc. 2569. 
fazer côngrua ao Rdo. Vigário". ${ }^{25}$ A freguesia havia perdido 28 famílias, das 63 que possuía, da paragem chamada Ponte Alta distrito da vila de Jundiaí, distante das Campinas duas léguas e seis de Jundiaí. Argumenta Leme que não podem os pobres sujeitar-se à "longitude de seis léguas, deixando a de duas". O pagamento dos párocos era responsabilidade dos moradores e cada freguesia buscava aumentar, ou ao menos não diminuir, a quantidade de moradores e a sua capacidade de contribuição.

Não eram apenas os dízimos uma novidade para muitos habitantes destes sertões, até mesmo o rei era desconhecido em algumas paragens. Em ofício de 20 de junho de 1768 queixa-se o governador ao conde de Oeiras de que

o respeitável nome de $\mathrm{S}$. Majde. que Deus guarde era desconhecido em alguns lados onde apenas se tinha ouvido que havia general, tais sendo os retiros de Jaguari, de Camanducaia, dos bairros de Assariguama junto ao Rio Paraíba, nos matos de Paranapanema, Piauí [ou Apiaí], e Ribeira e nos campos gerais, as Furnas e outros lugares.

Para dar cabo desta situação, diz D. Luís que estava fazendo "celebrar os dias de anos de Sua Majde. que Deus guarde, para imprimir cada vez mais nos ânimos dos Povos o Respeito e veneração que se lhe deve". $26 \mathrm{O}$ governador aproveita as novas povoações para tornar o rei e demais autoridades da Coroa mais conhecidos e venerados, dando-lhes seus nomes a elas, como a São José de Moji-mirim ou São José da Paraíba. O morgado de Mateus homenageia até a si próprio ao fundar a povoação de São Luís de Guaratuba (vila em 1770); para que não parecesse uma ousadia muito grande, pede autorização para dar o nome de São Luís à nova vila, bem como erigir igreja em honra de Nossa Senhora dos Prazeres, virgem de sua devoção pessoal, "em virtude de já existirem povoações com o nome de S. José e S. Sebastião não lhe ficando lugar portanto para pôr o nome do Rei ou do Conde". ${ }^{27}$ As auto-homenagens não param por aí, já que erige a vila de São Luís do Paraitinga, Prazeres das Lages e o presídio de Nossa Senhora dos Prazeres do Iguatemi.

25 BN, Carta de Francisco Barreto do Amaral ao governador da Capitania de São Paulo Luís Antônio de Souza Botelho Mourão, solicitando que se fizesse nova demarcação do local escolhido para aquela freguesia a fim de aumentar a população..., I-30, 13, 19 n 3. Arquivo de Mateus, doc. 100.

26 AHU, cx. 25, doc. 2413.

27 Ibid., cx. 24, doc. 2274. Ofício de 1 de dezembro de 1765. 
Subordinação necessária já que, tratando da dificuldade de fundar povoações nas capitanias do sul afirma o governador que a experiência lhe havia mostrado

a grande oposição que têm os Povos às fundações de Povoações Civis: os pequenos porque querem viver na liberdade, na dissolução, e os maiores porque querem servir-se daqueles mesmos debaixo do nome de administrados, e tê-los como verdadeiros escravos. ${ }^{28}$

Trata-se aqui de disciplinar os índios, os "pequenos" de que fala o governador, trazendo-os à civilidade, e também os "maiores", interessados na "administração" destes índios como vinham fazendo seus antepassados havia muitas gerações, submetendo estes interesses particulares ao "bem comum". Por isso resistem todos à sujeição às leis do Reino ou da Igreja; ao menos é assim que justifica o governador ao vice-rei as dificuldades em convencer a população da capitania em obedecer aos chamados de povoamento, muitas vezes em locais hostis como era o caso do Iguatemi, aos violentos recrutamentos militares e à cobrança dos impostos. A oposição vinha também dos párocos que não desejavam ver suas paróquias divididas ou diminuídas, como se queixou D. Luís Antônio ao marquês de Pombal em 1771, e "de nenhum modo se querem acomodar a que haja outros Vigários inda que seja em terras adonde nunca houvesse nada". ${ }^{29}$ Um ano antes, em 9 de julho de 1770, já se queixara de que a repartição das freguesias podia estar muito mais adiantada se não fossem as oposições dos párocos confinantes, "não querendo consentir em ceder nada dos seus distritos". 30

Por isso, a vigilância necessária para impedir qualquer morador de viver isolado da vida civil e conversável, necessária à sujeição dos povos, mesmo que não fosse a grande distância da cidade de São Paulo. É o que acontece em 19 de setembro de 1768, quando o governador notifica Matias Lemos e dois filhos, que se achavam morando no bairro de Tremembé, "em uma casa coberta de palha sem mais lavoura, ou situação permanente, por cuja causa vem a entrar no $\mathrm{n}^{\circ}$ dos sítios volantes, que S. Maje. manda proibir", para que passem a viver, no termo de quinze dias, "em qualquer lugar arruado desta Capitania" que tivesse mais de cinqüenta vizinhos. ${ }^{31}$ Não é apenas o isolamento da vida urbana mas também o viver

28 DI, v. 23, p. 204. Carta ao vice-rei de 7 de julho de 1767.

29 AHU, São Paulo, Mendes Gouveia, cx. 27, doc. 2569. Ofício do governador acerca da utilidade das novas povoações..., 4 de setembro de 1771 .

30 DI, v. 34, p. 255.

31 Tbid., v. 65, p. 223. 
sem "situação permanente", sem ofício ou roça, sem nenhuma produção, que se procura evitar com a proibição dos sítios volantes e dos moradores dispersos.

Para impedir as fugas das povoações, o governador proíbe, por meio de bando de 26 de fevereiro de 1766, referente à vila de Paranaguá, que se deserte das povoações para os matos "com total prejuízo da república e escândalo dos naturais", sob pena de prisão. ${ }^{32}$ Por ordem do rei, em carta de 2 de julho deste mesmo ano, são proibidos os sítios volantes, povoações itinerantes sem jurisdição dos poderes constituídos, com ordem para que os moradores se juntem em povoações civis de cinqüenta vizinhos para cima. ${ }^{33}$ No entanto, em carta ao conde de Oeiras, afirma que a acertada disposição de manter os homens em povoações civis depende "da emenda e método da lavoura" que garantisse a produção e o abastecimento, sem os quais não seria possível acabar com estes sítios volantes. Afirma aqui ao ministro as dificuldades na manutenção dos povoados criados pelo atraso da agricultura, sobretudo pela insistência dos paulistas em aceitar suas inovações e a "racionalização" da produção. Numa carta a seu cunhado governador de Angola, Francisco Inocêncio de Souza Coutinho, o morgado de Mateus dá uma cara mais nítida a estes paulistas que se recusavam a viver em civilidade: não eram os moradores decentes de São Paulo, mas "os gentios livres e acostumados a viver pelos matos sem sujeição, ou civilidade alguma”. ${ }^{34}$

Estas povoações destinavam-se às pessoas "miseráveis" e sem estabelecimento certo; para atraí-las e evitar as deserções, determina em 18 de abril de 1771 que os povoadores das novas povoações não fossem "vexados, ou por crimes ou por dívidas com que antecedentemente se achassem embaraçados", já que a execução da justiça, nestes casos, apenas contribuiria para que as terras se despovoassem mais rapidamente, com prejuízo para o Estado e para S. Majestade. Determina que a justiça se ocupasse apenas das "cousas que sucederem" e das dívidas que se contraíssem entre os uns e outros moradores; dos crimes antigos a justiça só tomaria conhecimento com ordem especial do capitão-general. ${ }^{35}$ Além disso, o governador também premiava os súditos que contribuíssem para o crescimento das povoações, como faz com Antônio de Souza, que em troca de cumprir com toda a despesa de construção da

32 Ibid., p. 48-49.

3 Ibid., v. 23 , p. 8.

34 Ibid., v. 19, p. 397.

35 Ibid., v. 33, p. 34. 
igreja matriz de São Luís de Guaratuba é remunerado com a patente de capitão-mor do distrito, que D. Luís eleva em seguida à condição de vila. ${ }^{36}$ Premiar os colaboradores e punir os rebeldes: em maio de 1771 a câmara de Taubaté escreve ao governador pedindo providências contra o capitão José Correia Leme Marzagão pelo mau exemplo que dava aos demais moradores, recusando-se a concorrer para a construção da igreja matriz da vila, que "alteradamente responde a qualquer notificação da nossa parte feita com ousadia e sem decoro nem atenção a Câmera, e seus oficiais". Preocupa-se a câmara pois esta "temerária resolução" do capitão Marzagão podia servir de mau exemplo aos demais e pretexto para se negarem a colaborar. Os vereadores têm de pedir a assistência do governador por não poderem proceder contra ele, em atenção do cargo que ocupava, "fiado no qual nunca assiste ao que é do bem comum". ${ }^{37}$ A vida em povoações "civis e conversáveis" implicava um aprendizado de convivência, ou seja, dos deveres que os republicanos tinham para com o bem comum e o engrandecimento do reino. Se os vadios e dispersos, os "desclassificados" da colônia, eram os objetos freqüentes das preocupações do Estado como fonte de sedição e desobediência, muitas vezes os potentados e poderosos locais também tinham de ser punidos para exemplo das "baixas esferas". É verdade que poderiam receber a mercê das autoridades, de acordo com suas ligações pessoais, mas obrigando-se de qualquer forma a algum tipo de sujeição à autoridade que os perdoava, enquadrando-se no sistema. Um edital de 22 de outubro de 1771 dá uma indicação de que o governador procurava disciplinar os poderes locais: por ele se determinava que nenhuma pessoa, de qualquer qualidade ou condição que fosse, lhe falasse ao capitão-general em benefício de presos, recrutados à força para as tropas, "que vêm na presente Leva, sob pena de caírem no desagrado do mesmo Senhor". 38 A pena parece estar implícita no desagrado que os faltosos causariam ao senhor governador, não sendo necessário explicitar o castigo.

Por isso, não há contradição entre o desejo de civilizar os dispersos que vivam como feras e o perdão dos crimes dos povoadores, numa limitação desta mesma justiça que se desejava levar aos "habitadores" do sertão. A lei no Antigo Regime é mais indicativa do que normativa, podendo adaptar-se às condições da terra: perdoar os criminosos e faltosos não era uma mercê que se fazia a

36 Ibid., p. 199-200. Carta ao conde de Oeiras, 27 de março de 1770.

37 BN, I-30, 22, 18 n 17. Arquivo de Mateus, doc. 161.

38 DI, v. 33, p. 37. Edital para ninguém interceder pelas novas recrutas. 
estas "feras" do sertão mas uma utilidade que se dava a estes homens, que representavam um peso para a Coroa, em proveito do Reino. Era uma forma de civilizá-los, e ao mesmo tempo acrescentar riquezas à Coroa; ao ordenar à câmara de São Vicente que obrigasse a seus moradores terem casa na vila e viverem juntos, em "sociedade civil" e em "casas arruadas", o governador afirma que isso era necessário pois era assim que viviam todas as nações polidas, "porque a emulação que nasce de se quererem os homens adiantar uns aos outros, faz desterrar a preguiça que é a origem da pobreza". ${ }^{39}$ É desta civilidade que trata o morgado de Mateus: a vida em sociedade e sujeição, em povoações arruadas, com o controle da justiça e da religião, a concorrência, salutar ao crescimento dos negócios; que não exclui a "polidez" cortesã e o conhecimento "enciclopédico", mas não se resume apenas a eles. Trata-se menos de uma civilidade de modos do que de uma atitude política de respeito à Coroa e aos seus governantes, embora uma etiqueta da hierarquia e do respeito às autoridades não seja negligenciada pelo governador. As cidades e povoações serão o espaço onde se desenrolará o aprendizado desta sujeição, onde se buscará impor uma cultura letrada, ou práticas letradas de justiça, representativas do poder do Estado, sobre populações que ainda mantêm uma "relação muito estreita (praticamente exclusiva) com os processos administrativos tradicionais". ${ }^{40}$ E São Paulo é o local a partir do qual esta sujeição se espraia ao resto da capitania.

\section{O recenseamento de 1765 e a reorganização espacial de São Paulo}

A reorganização do território será uma das principais preocupações do governador; um dos seus primeiros atos foi a realização de um censo, cujo objetivo era um conhecimento maior da população, das potencialidades de produção e de renda e organizar as ordenanças, para se saber com quem poderia contar para a formação das tropas. Os recenseamentos são uma prática ilustrada de conhecimento do território iniciada na segunda metade do século XVIII na Inglaterra. No Brasil o censo paulista antecede a idéia do marquês do Lavradio, anotada no Relatório ao vice-rei que o vinha substituir em 1779, sobre a necessidade de arrolar toda

39 Ibid., v. 67, p. 170-171.

40 Hespanha, António Manuel. Centro e periferia nas estruturas administrativas do Antigo Regime. Ler História, Lisboa, 8, 1986, p. 51. Cf. do mesmo autor As vésperas..., op. cit., p. 225. 
a população colonial em corpos de ordenança organizados, "a fim de tê-la assim facilmente ao alcance da administração sujeita a ela e governável" ${ }^{41}$ Em edital de 9 de maio de 1772, ano em que se realiza um outro censo mais completo, o governador requer aos lavradores da cidade e suas freguesias que informem tudo o que haviam plantado na lavoura passada "a fim de saber-se o que cada um plantou para saber-se o que deve haver de acréscimo para a cultura deste ano e dos mais". ${ }^{42}$ Algum tempo depois, um edital exigia que todos os lavradores do termo da cidade dobrassem suas plantações de milho, feijão e arroz. ${ }^{43}$

O conhecimento da população e do território tinha como objetivo otimizar a administração e a produção da capitania e garantir a defesa contra inimigos externos, os eternos rivais castelhanos, e internos, os delinqüentes que passavam de uma capitania a outra sem medo da justiça. Assim, o governador se ocupou da reorganização espacial da capitania e da cidade de São Paulo numa tentativa de "racionalizar" a administração e o uso da terra e de seus recursos. Em Portugal à mesma época também se realizaria uma grande reorganização espacial, que no entanto é precedida pelas reformas do morgado de Mateus em São Paulo. A construção do Estado Moderno passa também "pela apropriação políticoadministrativa de um espaço que ele tendeu a unificar". Isso garantia uma "regularidade e fidelidade tão efetivas quanto possível das relações entre centro e periferia", unificando a legislação, o fisco e a justiça. ${ }^{44}$ Esta unificação de legislação acompanhava uma unificação do próprio espaço, que facilitaria "a recolha dos tributos, o recrutamento militar e o policiamento dos comportamentos". 45

Em finais do século XVIII, Portugal tentará introduzir melhoramentos nas comunicações do reino, na navegabilidade dos rios, reformando pontes e caminhos e denunciando os particularismos localistas e protecionistas, que se acusava de servirem aos interesses particulares de vereadores e câmaras, de entrar em contradição com a lei geral "e de estar na origem de fenômenos que se constituíam em outros tantos embaraços ao comércio interno e à vida econômica em geral", tais como a diversidade de pesos e medidas, de

41 Prado Jr., Caio. Formação do Brasil contemporâneo. 23ª ed., São Paulo: Brasiliense, 1995, p. 324.

42 ACMSP, v. XVI, p. 138.

43 Ibid., p. 148.2 jul. 1772.

44 Silva, Ana Cristina Nogueira da. O modelo espacial do Estado Moderno. Reorganização territorial em Portugal nos finais do Antigo Regime. Lisboa: Estampa, 1998, p. 19.

45 Id., ibid., p. 20. 
preços, multiplicidade de tributos e portagens. ${ }^{46} \mathrm{~A}$ divisão espacial de Portugal à essa época era descontínua, marcada pela sobreposição de circunscrições administrativas, fiscais e judiciais e pela coexistência de poderes locais que rivalizavam com a Coroa. O desejo de mudar esta situação levou à Lei de Reforma das Comarcas de 1790, na qual pela primeira vez se lançaram "os fundamentos de uma proposta de reforma global do território do Reino, estreitamente associada à reforma do sistema judicial. O que se visava era, no essencial, a uniformização da justiça régia e da administração do território". ${ }^{47} \mathrm{O}$ conhecimento do território torna-se uma arma importante da administração, tornando-se "inseparável do exercício da soberania". Também na França este conhecimento foi tributário do desenvolvimento de uma administração pública que tendia a cobrir o país "com uma rede simultaneamente mais apertada e mais regular". ${ }^{48}$ Esta reforma pretendia anexar pequenos concelhos e coutos a jurisdições maiores, acabar com territórios encravados, homogeneizar as leis e a "mentalidade" dos agentes da administração e impor a autoridade dos juízes-de-fora contra os poderes locais, valorizando-se o direito oficial e a cultura letrada representadas por ele, que era visto como um "agente privilegiado dos 'interesses públicos' que as justiças das terras lesavam, por servirem, em vez deles, apenas os particulares". ${ }^{49}$ Além dos poderes locais, o poder da Igreja também é questionado, pois as circunscrições da administração da Igreja, "ao remeterem para um centro político que não era a coroa mas que se exercia, por direito próprio, importantíssimas jurisdições, acabavam por ser fatores de dispersão".50

As ações do morgado de Mateus em São Paulo, se são contemporâneas do debate sobre as reformas espaciais necessárias à consolidação do Estado Moderno, antecedem bastante à lei de 1790, e mesmo o seu primeiro ensaio, a reforma político-territorial do Algarve, ocorrida em 1773, que redefiniu os termos de alguns concelhos, extinguindo alguns, para tornar a estrutura econômica e administrativa mais eficaz. ${ }^{51} \mathrm{O}$ governador também duvida da capacidade dos poderes locais atenderem ao "bem comum" e ao crescimento

46 Id., ibid., p. 35-36.

47 Id., ibid., p. 74.

48 Revel, Jacques. A invenção da sociedade. Lisboa/Rio de Janeiro: Difel/Bertrand, 1989, p. 121.

49 Silva, op. cit., p. 86.

50 Ibid., p. 52. Cf. Silva, Ana Cristina Nogueira da e Hespanha, António Manuel. O quadro espacial, in António Manuel Hespanha, António Manuel (coord.). História de Portugal, v. 4, O Antigo Regime (1620-1807). Lisboa: Estampa, 1992, p. 42-43.

51 Cf. Hespanha, As vésperas..., op. cit., p. 110. 
econômico da capitania, fosse pelos interesses locais, fosse pela preguiça e incivilidade. Para D. Luís Antônio, o território e o conhecimento que se podia ter dele eram "problemas políticos", que punham "em causa o destino da nação".52 Inicialmente, o governador ordena, em 13 de julho de 1769, que se defina o rocio da cidade, incerto desde a concessão por carta de sesmaria do rocio feita por Rodrigo César de Menezes em 1724, mandando que se procurassem os herdeiros de João Ramalho e Antônio Macedo e se medissem as suas datas "para se saber aonde acaba, e devem principiar as terras da Aldeia de S. Miguel". ${ }^{53}$ Os oficiais da câmara não encontram os tais herdeiros e ordenam a medição, em 26 de julho deste ano, aos moradores do bairro de Nossa Senhora da Penha que viviam onde se supunha estivessem as terras de João Ramalho. Ao mesmo tempo a câmara cumpria a determinação do governador de definir os limites da cidade com a nova vila de São João de Atibaia.54 A demarcação estabelece os famosos marcos da meia légua, tendo em seu centro o largo da Sé e formando uma circunferência de três quilômetros de raio.

Assim como a reforma de 1790 em Portugal se ocupou dos concelhos muito pequenos, ou de população muito dispersa, D. Luís Antônio se preocupa com as freguesias da capitania: informa ao conde de Oeiras que aqui havia 38 freguesias, "destas há algumas com doze, vinte, e mais léguas de comprido, e outro tanto de largo, e nesta distância estão dispersos os seus Fregueses". ${ }^{55} \mathrm{O}$ tamanho excessivo das freguesias, a distância das povoações, contribuía para que vivessem os fregueses isolados do convívio civilizado, indo raras vezes à missa, batizados muitas vezes depois de adultos, vivendo apenas de suas roças sem proveito para o Estado. Para a elevação da povoação de Apiaí a vila, justifica que a povoação se achava a grande distância de vilas que tivessem justiças, "não podendo estas satisfazer as suas obrigações, seguindo-se todos aqueles inconvenientes que desta falta se costumam seguir aos Povos". ${ }^{6}$ Em ofício ao conde de Oeiras de 18 de fevereiro de 1768, afirma que algumas das freguesias da capitania "ainda necessitavam se regularem melhor quanto à sua repartição, não só para que os Povos possam com comodidade acudir aos Ofícios Divinos, mas também para que os Párocos possam com mais facilidade administrar-lhes os sacramentos". ${ }^{57}$

52 Revel, op. cit., p. 127-128.

53 DI, v. 92, p. 56

54 ACMSP, v. XV, p. 480-481

55 DI, v. 23, p. 4. Carta ao conde de Oeiras de 23 de dezembro de 1766.

56 Ibid., v. 33, p. 31. Ordem para a elevação de Apiaí a vila, 14 de agosto de 1771.

57 AHU, São Paulo, Mendes Gouveia, cx. 23, doc. 2395. 
Dessa forma, São João de Atibaia é elevada a vila em 1769, sendo ainda Nazaré e Jaguari desmembradas de São Paulo, o que, segundo Marcílio, levou muitos historiadores a verem uma suposta estagnação ou decadência na população da cidade neste período. ${ }^{58}$ No auto de ereção de Atibaia destaca-se que deveriam ser elevadas a vilas aquelas povoações que fossem mais "próprias para o dito efeito", sendo esta "uma das mais que se distinguem em os requisitos necessários para receberem a honra do nome de Vila. ${ }^{59}$ Ocupam-se os oficiais da nova vila de determinar as divisões de seu termo com a cidade de São Paulo e com a vila de Jundiaí. A preocupação em determinar exatamente as divisas do rocio era de não submeter a população a jurisdições sobrepostas, ficando os moradores "sujeitos no temporal a servirem uma Vila e no espiritual sujeitas a outras de que são fregueses, o que seria ônus muito penoso para os moradores e se trocaria o beneficio [a elevação a vila] que lhes faz S. Maje. que Deus Guarde em pena". ${ }^{60}$ Esta sobreposição de jurisdições, que era comum na disposição espacial do Antigo Regime já não era mais tolerável para a administração do governo ilustrado em Portugal. Não se admitia tampouco a enormidade do território da cidade de São Paulo, cujo termo chegava à capitania das Minas, sendo desmembrada para que sua administração fosse otimizada e racionalizada de acordo com normas ilustradas de organização espacial que se impunham em fins do século XVIII.

E não podemos esquecer das tratativas para a definição dos limites não apenas da fronteira sul com os castelhanos, mas também com a capitania de Minas Gerais, ou ainda as disputas pelas jurisdições das novas vilas criadas pelo morgado de Mateus ${ }^{61}$; o governador do Rio Grande, José Custódio de Sá e Faria, afirmava que as fundações de Lages e do Iguatemi "significavam pretensões ilegais de D. Luís Antônio, uma vez que se situavam em território 'seu', no primeiro caso, e espanhol no segundo".62 Com relação às

58 Marcílio, Maria Luiza. A cidade de São Paulo: Povoamento e população, 1750-1850 (com base nos registros paroquiais e nos recenseamentos antigos): São Paulo: Pioneira/Edusp, 1973, p. 98.

59 DI, v. 34, p. 152.5 de novembro de 1769.

60 Ibid., p. 159. Termo da divisão dos distritos da nova Vila de S. João de Atibaia com a cidade de S. Paulo e Vila de Jundiaí. 5 de novembro de 1769.

61 Sobre as fronteiras do sul cf. Almeida, Luís Ferrand de. O problema da fronteira no sul do Brasil: o caso da colônia do Sacramento. In: Albuquerque, Luís (dir.). Portugal no mundo. Lisboa: Alfa, 1989, p. 191-201; e Marques, Alfredo Pinheiro. O papel dos cartógrafos e dos engenheiros militares na fixação dos limites do Brasil. In: Ibid., p. 180-190.

62 Bellotto, op. cit., p. 182. 
Minas Gerais, além da racionalização da administração contava também o controle sobre minas de metais e pedras preciosas, tendo ocasionado conflitos entre o morgado de Mateus e o conde de Valadares, capitão-general de Minas Gerais, que enviara tropas para descobertos que D. Luís Antônio considerava como pertencentes a São Paulo.63 Definir os limites espaciais passa a ser condição indispensável da administração tanto no Reino como em suas possessões, significando a racionalização do controle, a extensão do poder e o aumento das rendas da Coroa.

\section{Siglas}

ACMSP Actas da Camara da Cidade de São Paulo.

AHU Arquivo Histórico Ultramarino (Lisboa). Projeto Resgate.

BN Biblioteca Nacional (Rio de Janeiro).

DI Documentos Interessantes para a História e Costumes de São Paulo.

RAMSP Revista do Arquivo Municipal de São Paulo.

\section{Referências}

ALMEIDA, Luís Ferrand de. O problema de fronteiras no Sul do Brasil: o caso da colónia do Sacramento. In: ALBUQUERQUE, Luís (dir.). Portugal no mundo. Lisboa: Alfa, 1989, v. 5, p. 191-201.

BELLOTTO, Heloísa Liberalli. Autoridade e conflito no Brasil: o governo do Morgado de Mateus em São Paulo: 1765-1775. São Paulo: Conselho Estadual de Artes e Ciências Humanas, 1979.

BICALHO, Maria Fernanda B. O urbanismo colonial e os símbolos de poder: o exemplo do Rio de Janeiro nos séculos XVII e XVIII. Estudos IberoAmericanos, Porto Alegre, PUCRS, v. 24, n. 1, p. 31-57, 1998.

CENTURIÃO, Luiz Ricardo Michaelsen. A cidade na América colonial portuguesa. Estudos Ibero-Americanos, Porto Alegre, PUCRS, v. 22, n. 1, p. 121-133, 1996.

HESPANHA, António Manuel. Centro e periferia nas estruturas do Antigo Regime. Ler História, Lisboa, n. 8, p. 35-60, 1986.

(coord.). História de Portugal. V. 4: O Antigo Regime (1620-1807). Lisboa: Estampa, 1992.

. As vésperas do Leviathan. Instituições e poder político em Portugal séc. XVII. Coimbra: Almedina, 1994.

HOLANDA, Sérgio Buarque de. Caminhos e fronteiras. São Paulo: Companhia das Letras, 1995.

63 Ibid., p. 236 e segs. 
JARDIM, Caio. A Capitania de São Paulo (sob o governo do Morgado de Mateus, 1765-75). RAMSP, São Paulo, v. 5, n. 53, p. 5-82, 1939.

LEWCOWICZ, Ida. Morgado de Mateus. In: VAINFAS, Ronaldo (org.). Dicionário do Brasil Colonial. Rio de Janeiro: Objetiva, 2000.

KUZNESOF, Elizabeth A. Household economy and urban development: São Paulo, 1765 to 1836. Boulder, CO: Westview, 1986.

MARCÍLIO, Maria Luiza. A cidade de São Paulo, povoamento e população. 17501850 (com base nos registros paroquiais e nos recenseamentos antigos). São Paulo: Pioneira, Edusp, 1973.

MARQUES, Alfredo Pinheiro. O papel dos cartógrafos e dos engenheiros militares na fixação dos limites do Brasil. In: ALBUQUERQUE, Luís (dir.). Portugal no mundo. Lisboa: Alfa, 1989, v. 5, p. 180-190.

MIRANDA, Lilian Lisboa. Governança e edilidade em São Paulo (1765-1775). São Paulo: USP, 2003 (tese de doutorado).

MONTEIRO, Nuno Gonçalo F. Trajetórias sociais e governo das conquistas: notas preliminares sobre os vice-reis e governadores-gerais do Brasil e da Índia. In: FRAGOSO, João; BICALHO, Maria Fernanda; GOUVÊA, Maria de Fátima (orgs.). O Antigo Regime nos trópicos: a dinâmica imperial portuguesa (séculos XVI-XVIII). Rio de Janeiro: Civilização Brasileira, 2001.

MOURA, Américo Brasiliense Antunes de. O governo do Morgado de Mateus no vice-reinado do Conde da Cunha. S. Paulo restaurado. RAMSP, São Paulo, v. 5 , n. 52, p. $1-155,1938$.

NEME, Mário. Um governador reformista no São Paulo colonial. Anais do Museu Paulista. São Paulo, t. 34, p. 9-53, 1970.

PRADO JR., Caio. Formação do Brasil contemporâneo. Colônia. 23. ed. São Paulo: Brasiliense, 1995.

REVEL, Jacques. A invenção da sociedade. Lisboa/Rio de Janeiro: Difel/Bertrand, 1989.

SILVA, Ana Cristina Nogueira da. O modelo espacial do Estado Moderno. Reorganização territorial em Portugal em fins do Antigo Regime. Lisboa: Estampa, 1999.

VIANNA, Hélio. São Paulo no Arquivo de Mateus. Rio de Janeiro: BN, Divisão de Publicações e Divulgação, 1969. 